\title{
Impact of Meteorological Drought in Upper Blue Nile Basin on the Hydrological Drought of Nile River in Egypt
}

\author{
Eman H Mabrouk, Fawzia I Moursy, Mostafa A Mohamed, Mohie El Din M Omar
}

\begin{abstract}
Precipitation over the Upper Blue Nile Basin in Ethiopia contributes with $85 \%$ of the Nile river which provides 93\% of Egypt's conventional water resources. This study aims at assessing the meteorological drought in different locations in the Upper Blue Nile Basin and their relationship with the hydrological drought of Nile river in Egypt. The metrological drought was calculated by the Standard Precipitation Index (SPI) at five stations inside and close to the Upper Blue Nile Basin in Ethiopia, whereas the hydrological drought was calculated by the Streamflow Drought Index (SDI) at Dongola station at Nasser lake entrance. Both indices were calculated using the Drought Indices Calculator (DrinC) software. The selected study period was from 1973 to 2017 based on the availability of recorded data for meteorological stations in Ethiopia, and the streamflow for Dongola station. The data was categorized for each station by considering time periods of $1,3,6,9$, and 12 months based on their homogeneity. The correlation between SPI and SDI was evaluated using the Pearson correlation coefficient. The results showed a correlation between SPI for the five stations in the Upper Blue Nile Basin and SDI for Dongola station, where Gore station represented the highest frequency of significance at different time scales especially at the 3-months' scale. The results confirm the relationship between SPI at Gore Station and SDI at Dongola Station, which means that the hydrological drought in Egypt is highly affected by the meteorological drought in the area surrounding Gore station. The paper recommends improving techniques for monitoring and overseeing drought hazards and assessing more meteorological stations to accurately predict climate change variations in Upper Blue Nile Basin and its effect on Egypt's water resources.
\end{abstract}

Keywords: Meteorological drought; Standard Precipitation Index, Hydrological drought, Streamflow Drought Index

Revised Manuscript Received on July 10, 2020.

* Correspondence Author

Eman Hassan Mabrouk, Natural Resources Department, Faculty of African Postgraduate Studies, Cairo University, Egypt. E-mail: emandaha74@gmail.com

Fawzia Ibrahim Moursy, Natural Resourcs Department, Faculty of African Postgraduate Studies, Cairo University, Egypt. E-mail: fawzia254@cu.edu.eg

Mostafa Abdel Hamid Mohamed, Natural Resources Department, Facultiy of African Postgraduate Studies, Cairo University, Egypt. E-mail: mostafa_elhameed@cu.edu.eg

Mohie Eldin Mohamed Omar*, National Water Research Center (NWRC), Cairo, Egypt. E-mail: mohie.omar@hotmail.com

(C) The Authors. Published by Blue Eyes Intelligence Engineering and Sciences Publication (BEIESP). This is an open access article under the CC BY-NC-ND license (http://creativecommons.org/licenses/by-nc-nd/4.0/)

\section{INTRODUCTION}

Ethiopia has a diverse climate ranging from semi-arid desert type in the lowlands to humid and warm type in the southwest. Precipitation over the Upper Blue Nile Basin in the western part of Ethiopia contributes with 85\% of the Nile river. Egypt is as an arid country that depends on the Nile river which provides $93 \%$ of the country's conventional water resources (Omar, Moussa, 2016). The precipitation decline in the Upper Blue Nile Basin causes meteorological droughts, which subsequently cause hydrological droughts in the Nile river (Alrajoula et al., 2016). Drought indices are the most common methods to evaluate the severity of drought. There are several indices that assess meteorological droughts. In order to achieve accurate assessment of drought, the proper meteorological drought index should be selected for each region. Haied et al., (2017) compared the standardized precipitation index (SPI) with the Reconnaissance Drought Index (RDI) in Wadi Djelfa-Hadjia sub-basin, Algeria, and showed a good correlation at different time scales. Al Timimi, Osama (2016) compared four meteorological drought indices including the SPI, RDI, the Precipitation Declines Index (PDI) and Rainfall Anomaly Index (RAI) in Iraq. The study showed strong positive linear correlations between all drought indices, however, the strongest correlation was found between SPI and RDI. Muumbi et al., (2017) used SPI and the Standardized Precipitation Evapotranspiration Index (SPEI) to identify meteorological droughts in Upper Kafue River Basin, Southern Africa, where both showed similar results. Pathak, Dodamani, (2019) compared the SPI, RDI and SPEI in the Ghataprabha river basin in India and showed that SPEI did not harmonize with RDI and SPI indices at any timescale of the study period. The study also recommended to consider SPI in humid regions. Jamshidi et al, (2012) compared RDI and SPI on 41 synoptic stations placed in different parts of Iran with more than 30 years of data. The results showed that both indices behave in the same manner, but RDI is the proper drought index for Iran since it is a semi-arid region. From previous literature, it is clear that the SPI is the most proper index for assessing the meteorological drought in humid regions. It also showed a good correlation with all other drought indices except for the SPEI. Moreover, the SPI is distinct among other indices that it can determine and monitor drought at different time scales from 1 to 24 months (Boudad et al., 2018, Haied et al., 2017,

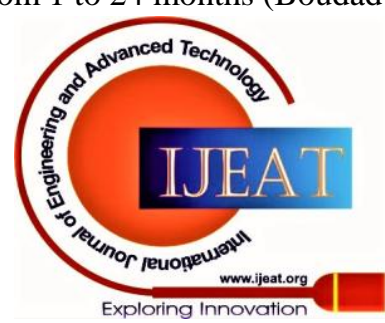


Vicente et al., 2010). Hence, the current study utilized the SPI in the Upper Blue Nile Basin in Ethiopia as a humid region at different time scales.

As for assessment of hydrological drought, the Streamflow Drought Index (SDI) and Standardized Runoff Index (SRI) are the most common indices worldwide.

They showed good correlation based on monthly observed streamflow volumes at different time scales (Boudad et al., 2018, Tsakiris et al., 2013, Pathak, Dodamani 2016). Muumbi et al., 2017 used the SRI to illustrate hydrological droughts in Upper Kafue River Basin of Zambia from 1984 to 2013. Özcan et al., 2019 used the SDI to determine the highest and lowest period of hydrological drought of Baykan Station in the Tigris Basin, Turkey in the period 1955 - 2016 for time scales of 1, 3, 6 and 12 months. Akbari et al., 2015 assessed the hydrological drought in Chenar Rahdar river, southern Iran over the period 1974 - 2013 for time scales of 3, 6, 9, and 12 months. The results confirmed the capability of SDI to capture the major droughts in Chenar Rahdar river.

Egypt is unique among nations in terms of its dependence on one determinant water resource. The water deficit, high population growth, and uncertainty of climate change impacts represent the most forbidding obstacles against the sustainable development. Nevertheless, to the authors' knowledge, there are no studies focusing on the impacts of meteorological droughts at different locations in the Upper Blue Basin on the hydrological droughts of Nile river in Egypt. Therefore, the current research objectives are: i) to assess the meteorological drought over the Upper Blue Nile Basin in Ethiopia using the SPI, ii) to assess the hydrological drought of the Nile river at Dongola station using the SDI, and iii) to find the correlation between both droughts and determine the locations that have the most significant effect.

\section{METHODOLOGY}

\section{A. Study Area}

The study area is in Ethiopia specifically the Upper Blue Nile Basin. Ethiopia is situated between $3^{\circ}$ to $15^{\circ} \mathrm{N}$ latitude and $33^{\circ}$ to $48^{\circ} \mathrm{E}$ longitude, with a total area of 1.13 million $\mathrm{km} 2$. The region is characterized by highly irregular topography in the central and northern highlands, and the lowland of the rift valley plain with elevation that ranges from $-125 \mathrm{~m}$ at the Denakil Depression to $4620 \mathrm{~m}$ at Ras Dejen. The temperature varies from north to south and it increases to the southeast region and decrease to the central part. The southwest of the country is characterized by the maximum precipitation, while the southeast has the minimum precipitation (Dawit, 2010, Romilly and Gebremichael, 2011). Ethiopia has three seasons of rain; Kiremt is from June to September, Bega is from October to January, and Belg is from February to May. Ethiopia has a diverse climate due to its equatorial positioning and the climate ranges from a semi-arid desert in the lowlands to humid and warm in the southwest. According to data availability, there are only five meteorological stations that that are located inside or close to the Upper Blue Nile Basin namely: Addis Ababa, Bahar Dar, Debremarkos, Gondar and Gore stations (Figure 1).

\section{B. Data Collection}

The data used in this study included monthly precipitation, and minimum and maximum temperatures at the five meteorological stations in Ethiopia, at streamflow data at Dongola station, since this station is utilized to quantify the water arriving Nasser lake. These values were used to calculate the SPI and SDI indices. The period of study was from 1973 to 2017, which has been chosen depending on the availability of recorded data for all stations.

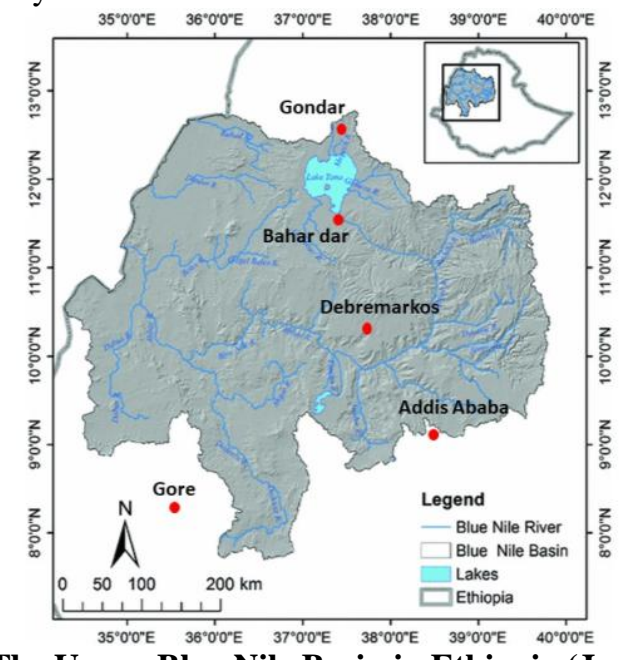

Fig 1: The Upper Blue Nile Basin in Ethiopia (Jarvis et al. 2008), and the selected stations

\section{Calculation of SPI and SDI indices}

Drought can be measured and analyzed by different indices. In this study, the SPI and SDI were used. The SPI is progressively proper for observing drought in East African since it is effectively adjusted to the local climate (Ntale and Gan, 2003). The SPI can be computed for different time scales and is based on the long-term precipitation record. This long-term record is fitted to a probability distribution. SPI was obtained by the following equation.

$$
S P I_{i k}=\frac{R_{i k}-M R_{k}}{S_{k}}
$$

$R_{\text {ik }}$ - high cumulative rainfall for the basis period (k) relating to (i) hydrological year

$M R_{k}$ - the mean height of cumulative rainfall

$S_{k}$ - the standard deviation of cumulative rainfall

SDI was also used to characterize the hydrological drought at Dongola station, and was obtained by the following equation. $S D I_{i k}=\frac{V_{i k}-M V_{k}}{S_{k}}$

$V_{\text {Ik }}$ - volume flow for the basis period (k) relating to (i) hydrological year

$M V_{k}$ - the mean total volume flow

$S_{k}$ - the standard deviation of cumulative flow volume

In order to facilitate the process, Drought Indices Calculator (DrinC) software was used in this study (Figure 2). The software was developed at the National Technical University of Athens (Tsakiris et al., 2007).

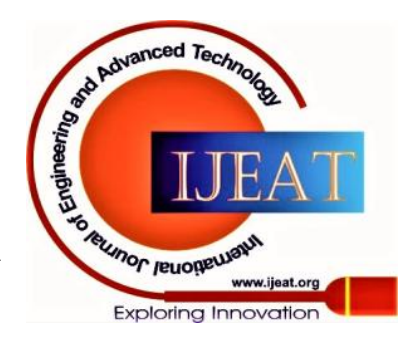


After calculating the SPI and SDI values, drought was assessed and classified as shown in Table I.

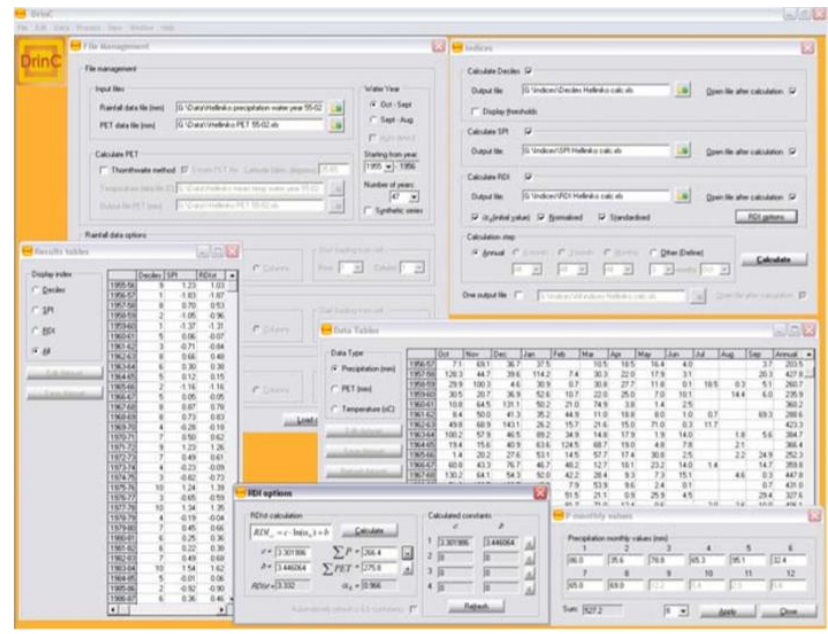

Fig 2: The main interface of DrinC software

Table I: Classification of drought (Hong et al., 2014)

\begin{tabular}{|c|c|}
\hline Index values SPI or SDI & Category \\
\hline 2.00 or more & Extremely wet \\
\hline 1.50 to 1.99 & Severely wet \\
\hline 1.00 to 1.49 & Moderately wet \\
\hline 0 to 0.99 & Normal conditions- wet \\
\hline 0 to -0.99 & Normal conditions - dry \\
\hline-1.00 to -1.49 & Moderate Drought \\
\hline-1.50 to -1.99 & Severe Drought \\
\hline-2 or less & Extreme Drought \\
\hline
\end{tabular}

\section{Correlation between SPI and SDI}

The relationship between meteorological drought at different locations in the Upper Blue Nile Basin and hydrological drought of Nile river flow at Dongola station, Pearson correlation coefficient was calculated between SPI and SDI at different time scales for 1, 3, 6 and 12 months. Pearson correlation coefficient was used to measure the degree or strength of relationship. Its values are in the range from -1 to 0 to +1 . If $r$ is close to 0 , it means there is no relationship between variables. A positive correlation coefficient indicates a direct relationship between the variables. A negative correlation indicates an inverse relationship between the two variables.

\section{RESULTS AND DISCUSSION}

\section{A. Evaluation of SPI in Ethiopia}

The calculation of SPI values in this study aimed firstly at assessing the meteorological drought over the entire country of Ethiopia. Then, it aimed at finding the correlation between meteorological drought at different locations in the Upper Blue Nile Basin in Ethiopia and the hydrological drought of Nile river. After calculation of SPI values, Figure (3) shows the SPI distribution over Ethiopia. It was noticed that Kirmet is the main rainy season for most of the country, in which extremely heavy precipitation falls except for the south and south-eastern parts. Belg is the main rainy season for the south and south-eastern. This was in agreement with Dawit, (2010) and Shang et al., (2011).

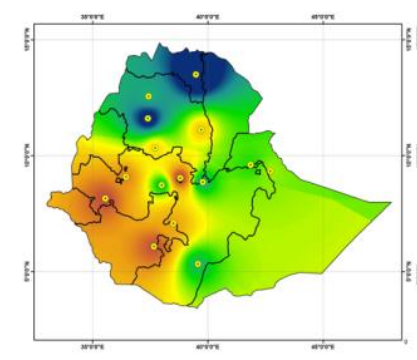

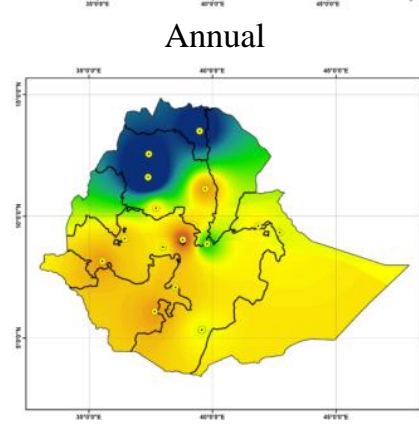

Belg season

$\begin{array}{lll}0 & 0.32 & 0.64\end{array}$

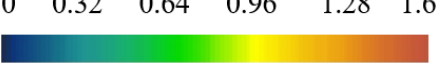

Fig 3: the distribution of SPI values in Ethiopia

\section{B. Correlation between SPI in Ethiopia and SDI in Egypt}

Figure 4 shows the monthly SDI and SPI, and Figure 5 shows the annual SDI and SPI and their trend during the period from 1973 to 2017. A number of hydrological droughts were noticed, where the most extreme drought took place during the period from 2002-2004. On the other hand, fewer meteorological droughts were noticed during these periods. It was also noticed that the values of SPI at Gore station and SDI at Dongola station indicate droughts in the same periods of time. Among the five stations, Gore station was the most correlated station with Dongola station with a squared $R$ value of 0.491 .

Figure 6 shows the percentage of drought occurrences of monthly SDI for Dongola and monthly SPI for the five selected stations which is indicative of the correlation between the meteorological drought in stations of Ethiopia and the hydrological drought in Egypt. It is obvious that Addis Ababa, Debremarcos and Gore have the largest percentage of meteorological drought, and Dongola has almost the same value of the hydrological drought percentage as well.

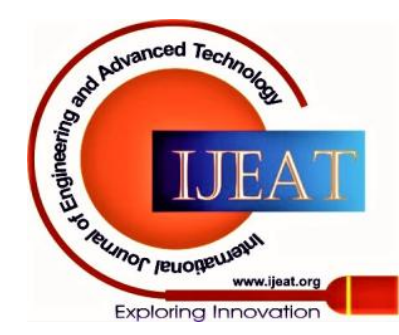




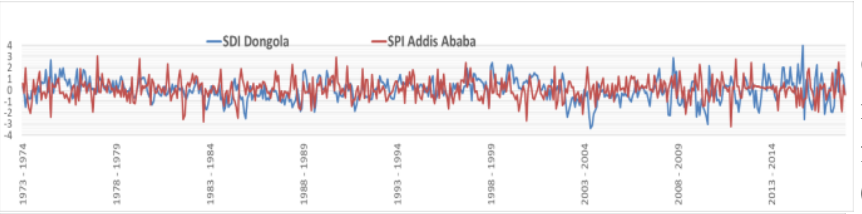

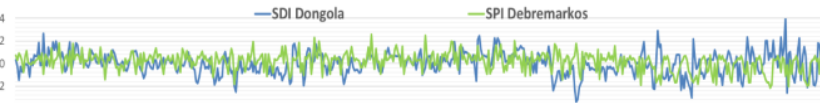

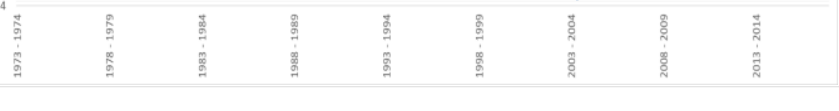

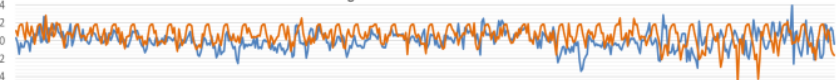

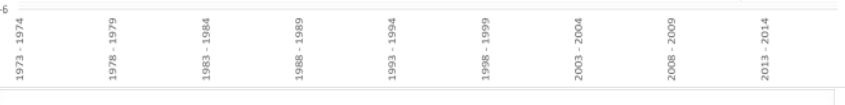
.

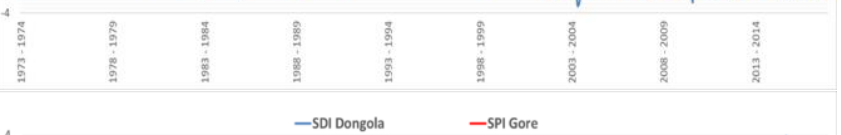

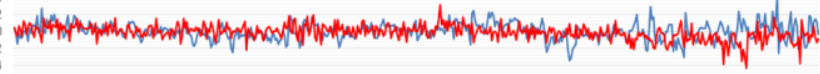

Fig 4: Monthly SPI for stations in Upper Blue Nile Basin and SDI for Dongola

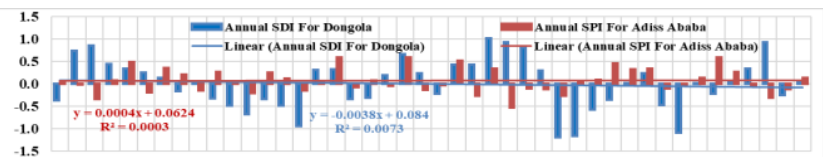
$-1.5$

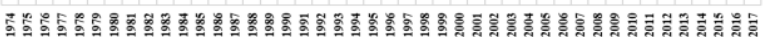

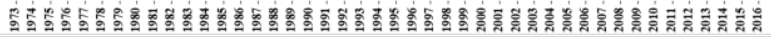

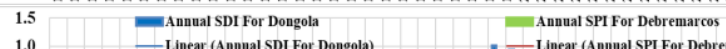

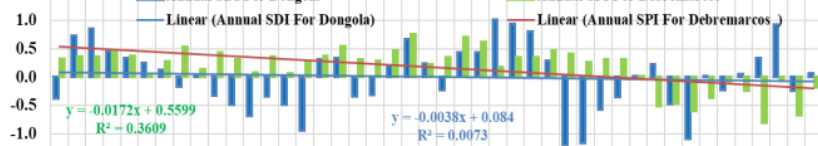
$-1.5$

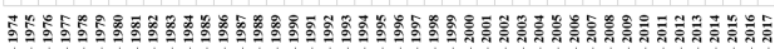

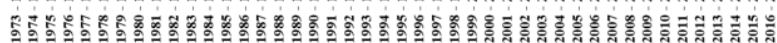

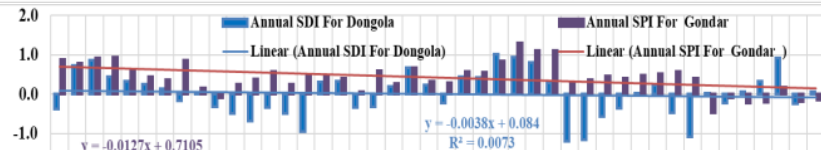

$-1.0$

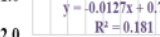

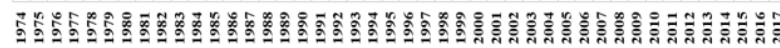

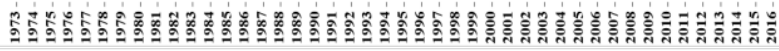
1.5

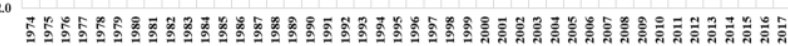

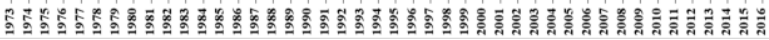

Fig 5: Annual SPI for stations in Upper Blue Nile Basin and SDI for Dongola station

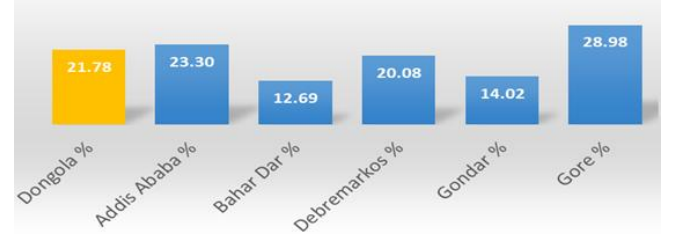

Fig 6: The drought percentage of SDI at Dongola station and SPI at the five stations (\%)
The Pearson correlation coefficient between SPI values at Gore station and SDI at Dongola station for 1, 3, 6, 9, 12 months are presented in Tables II, III, IV, V and VI. The frequency of statistical significance correlation at 0.01 and 0.05 levels is marked with yellow color. It is clear that the highest significance is found at the 3-months' scale, followed by the 6-months' scale, the 1-month scale, and least frequently at the 9-months' scale. While, no significance is found at the 12-months' scale.

The results confirm the relationship between SPI at Gore Station and SDI at Dongola Station, which means that the hydrological drought in Egypt is highly affected by the meteorological drought in the area surrounding Gore station.

Table II. The Pearson correlation coefficients correlogram between SDI at Dongola station and SPI at Gore station at one-month time scale

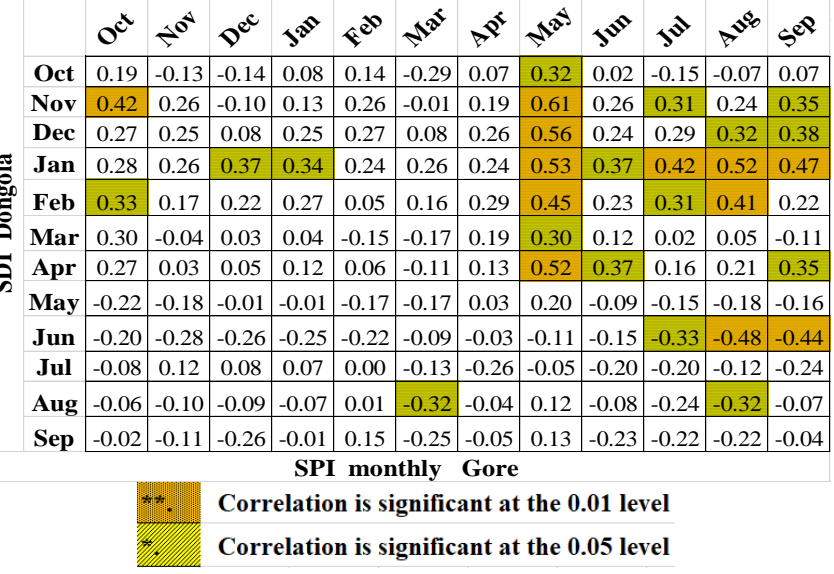

Table III. The Pearson correlation coefficients correlogram between SDI at Dongola station and SPI at Gore station at three-month time scale

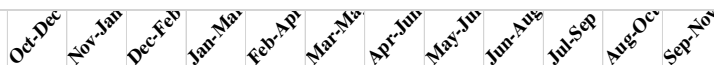
\begin{tabular}{l|l|l|l|l|l|l|l|l|l|l|l|l|}
\hline Oct-Dec & 0.27 & 0.01 & 0.06 & -0.01 & 0.14 & 0.41 & 0.39 & 0.25 & 0.07 & 0.07 & 0.11 & 0.14 \\
\hline
\end{tabular} \begin{tabular}{|c|c|c|c|c|c|c|c|c|c|c|c|c|}
\hline Nov-Jan & 0.48 & 0.30 & 0.30 & 0.25 & 0.36 & 0.63 & 0.58 & 0.53 & 0.38 & 0.38 & 0.43 & 0.43 \\
\hline
\end{tabular} \begin{tabular}{c|c|c|c|c|c|c|c|c|c|c|c|c|} 
T2 Dec-Feb & 0.46 & 0.41 & 0.42 & 0.35 & 0.42 & 0.65 & 0.57 & 0.55 & 0.48 & 0.49 & 0.47 & 0.43 \\
\hline
\end{tabular}

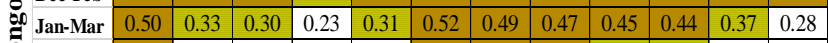
\begin{tabular}{l|l|l|l|l|l|l|l|l|l|l|l|l|}
\hline Feb-Apr & 0.46 & 0.19 & 0.15 & 0.05 & 0.18 & 0.48 & 0.49 & 0.44 & 0.36 & 0.32 & 0.22 & 0.13 \\
\cline { 2 - 8 }
\end{tabular} \begin{tabular}{|c|c|c|c|c|c|c|c|c|c|c|c|c|}
\hline Mar-May & 0.14 & -0.03 & -0.05 & -0.16 & 0.00 & 0.34 & 0.31 & 0.20 & 0.06 & 0.01 & -0.05 & -0.07 \\
\hline
\end{tabular} \begin{tabular}{l|l|l|l|l|l|l|l|l|l|l|l|l|l|}
\hline$-1.3 p r-J u n$ & -0.20 & -0.34 & -0.34 & -0.27 & -0.07 & 0.12 & 0.05 & -0.13 & -0.31 & -0.38 & -0.32 & -0.27 \\
\hline
\end{tabular}

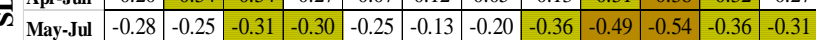
\begin{tabular}{|l|l|l|l|l|l|l|l|l|l|l|l|l|}
\hline Jun-Aug & -0.16 & -0.23 & -0.24 & -0.29 & -0.24 & -0.09 & -0.12 & -0.26 & -0.40 & -0.41 & -0.37 & -0.30 \\
\hline
\end{tabular} \begin{tabular}{|l|l|l|l|l|l|l|l|l|l|l|l|l|} 
Jul-Sep & -0.11 & -0.18 & -0.15 & -0.20 & -0.18 & -0.04 & -0.09 & -0.20 & -.334 & -.300 & -0.29 & -0.23 \\
\hline
\end{tabular} \begin{tabular}{|l|l|l|l|l|l|l|l|l|l|l|l|l|}
\hline Aug-Oct & -0.04 & -0.22 & -0.21 & -0.21 & -0.18 & 0.02 & -0.02 & -0.10 & -0.25 & -0.21 & -0.26 & -0.18 \\
\hline
\end{tabular} \begin{tabular}{l|c|c|c|c|c|c|c|c|c|c|c|c|} 
Sep-Nov & 0.03 & -0.14 & -0.17 & -0.12 & -0.11 & 0.12 & 0.06 & 0.04 & -0.13 & -0.09 & -0.10 & 0.02 \\
\cline { 2 - 9 }
\end{tabular} SIP3 Gore

Correlation is significant at the 0.01 level Correlation is significant at the 0.05 level

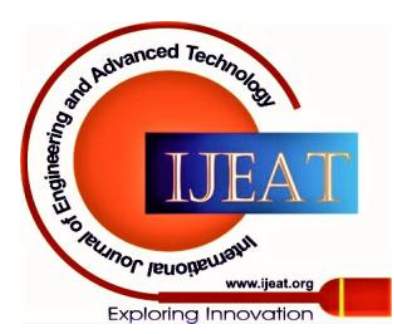


Table IV. The Pearson correlation coefficients correlogram between SDI at Dongola station and SPI at Gore station at six-month time scale

\begin{tabular}{|c|c|c|c|c|c|c|c|c|c|c|c|c|c|}
\hline & & $0^{c^{5^{5}}}$ & $5^{4}$ & $0^{e^{c^{(v)}}}$ & $y^{3}$ & $e^{e^{y^{y+y}}}$ & $4^{4}$ & $r^{r^{S^{4}}}$ & (4) & $v^{5^{4}}$ & $y^{8^{e^{c}}}$ & $\sqrt{00}^{408}$ & $g^{e^{x^{x^{x^{y}}}}}$ \\
\hline \multirow{12}{*}{$\begin{array}{l}\frac{\pi}{8} \\
0 \\
0 \\
0 \\
0 \\
0 \\
0 \\
0 \\
0\end{array}$} & Oct-Mar & 0.29 & 0.21 & 0.49 & 0.43 & 0.34 & 0.31 & 0.32 & 0.31 & 0.22 & 0.20 & 0.21 & 0.21 \\
\hline & Nov-Apr & 0.47 & 0.37 & 0.63 & 0.59 & 0.54 & 0.53 & 0.53 & 0.52 & 0.44 & 0.41 & 0.40 & 0.36 \\
\hline & Dec-May & 0.32 & 0.30 & 0.57 & 0.49 & 0.44 & 0.43 & 0.43 & 0.38 & 0.31 & 0.28 & 0.27 & 0.23 \\
\hline & Jan-Jun & 0.06 & 0.08 & 0.31 & 0.24 & 0.17 & 0.12 & 0.09 & 0.07 & -0.01 & -0.06 & -0.07 & -0.08 \\
\hline & Feb-Jul & -0.13 & -0.14 & 0.05 & -0.03 & -0.13 & -0.18 & -0.22 & -0.16 & -0.23 & -0.27 & -0.26 & -0.25 \\
\hline & Mar-Aug & $\begin{array}{l}-0.21 \\
\end{array}$ & $\begin{array}{l}-0.24 \\
\end{array}$ & -0.06 & -0.12 & -0.22 & -0.30 & -0.29 & -0.30 & -0.36 & -0.39 & -0.37 & -0.31 \\
\hline & Apr-Sep & $\begin{array}{l}-0.20 \\
\end{array}$ & -0.22 & -0.04 & -0.13 & -0.22 & -0.29 & -0.27 & -0.28 & -0.34 & -0.35 & -0.32 & -0.26 \\
\hline & May-0ct & -0.15 & -0.24 & -0.06 & -0.11 & -0.18 & -0.25 & -0.22 & -0.26 & -0.32 & -0.33 & -0.31 & -0.22 \\
\hline & Jun-Nov & -0.12 & -0.21 & -0.02 & -0.07 & -0.13 & -0.20 & -0.18 & -0.20 & -0.26 & -0.27 & -0.25 & -0.16 \\
\hline & Jul-Dec & -0.06 & -0.16 & 0.03 & -0.02 & -0.07 & -0.13 & -0.10 & -0.12 & -0.18 & -0.18 & -0.17 & -0.08 \\
\hline & Aug-Jan & -0.03 & -0.11 & 0.11 & 0.05 & 0.01 & -0.07 & -0.03 & -0.06 & -0.12 & -0.12 & -0.12 & -0.02 \\
\hline & Sep-Feb & 0.07 & 0.00 & 0.23 & 0.17 & 0.15 & 0.08 & 0.11 & 0.12 & 0.06 & 0.06 & 0.05 & 0.15 \\
\hline
\end{tabular}

Correlation is significant at the 0.01 level

Correlation is significant at the 0.05 level

Table V. The Pearson correlation coefficients correlogram between SDI at Dongola station and SPI at Gore station at nine-month time scale

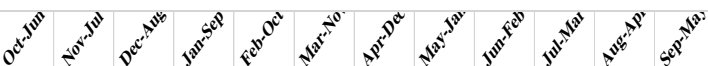

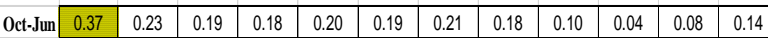

\begin{tabular}{|l|l|l|l|l|l|l|l|l|l|l|l|l|} 
Nov-Jul & 0.32 & 0.20 & 0.15 & 0.12 & 0.18 & 0.18 & 0.19 & 0.17 & 0.09 & 0.04 & 0.10 & 0.13 \\
\hline
\end{tabular}

\begin{tabular}{c|c|c|c|c|c|c|c|c|c|c|c|c|} 
ID Dec-Aug & 0.04 & -0.08 & -0.14 & -0.15 & -0.15 & -0.15 & -0.14 & -0.15 & -0.22 & -0.26 & -0.19 & -0.10 \\
\hline
\end{tabular}

\begin{tabular}{c|c|c|c|c|c|c|c|c|c|c|c|c|}
\hline & -0.22 \\
\hline
\end{tabular}

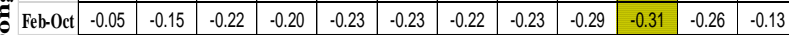

\begin{tabular}{l|c|c|c|c|c|c|c|c|c|c|c|c|c|}
$\boldsymbol{A}_{\text {Mar-Nov }}$ & -0.03 & -0.12 & -0.19 & -0.17 & -0.20 & -0.20 & -0.18 & -0.19 & -0.25 & -0.27 & -0.23 & -0.08 \\
\hline
\end{tabular}

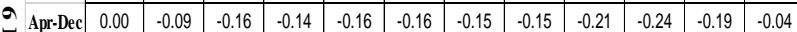

\begin{tabular}{c|c|c|c|c|c|c|c|c|c|c|c|c|}
\hline An May-Jan & 0.01 & -0.07 & -0.14 & -0.12 & -0.14 & -0.14 & -0.13 & -0.13 & -0.19 & -0.21 & -0.17 & -0.01 \\
\hline
\end{tabular}

\begin{tabular}{|c|c|c|c|c|c|c|c|c|c|c|c|c|}
\hline Jun-Feb & 0.04 & -0.04 & -0.11 & -0.09 & -0.11 & -0.11 & -0.10 & -0.10 & -0.15 & -0.17 & -0.14 & 0.02 \\
\hline
\end{tabular}

\begin{tabular}{|c|c|c|c|c|c|c|c|c|c|c|c|c|} 
Jul-Mar & 0.07 & 0.00 & -0.07 & -0.05 & -0.06 & -0.06 & -0.05 & -0.04 & -0.10 & -0.11 & -0.07 & 0.08 \\
\hline
\end{tabular}

\begin{tabular}{|l|l|l|l|l|l|l|l|l|l|l|l|l|} 
Aug-Apr & 0.11 & 0.04 & -0.02 & 0.00 & -0.02 & -0.02 & 0.00 & 0.00 & -0.06 & -0.07 & -0.04 & 0.13 \\
\hline
\end{tabular}

\begin{tabular}{l|l|l|l|l|l|l|l|l|l|l|l|l|} 
Sep-May & 0.21 & 0.15 & 0.09 & 0.11 & 0.12 & 0.12 & 0.13 & 0.14 & 0.07 & 0.06 & 0.08 & 0.26 \\
\hline
\end{tabular}

SPI 9 Gore

Correlation is significant at the 0.01 level

Correlation is significant at the 0.05 level

Table VI. The Pearson correlation coefficients correlogram between SDI at Dongola station and SPI at

Gore station at twelve-month time scale

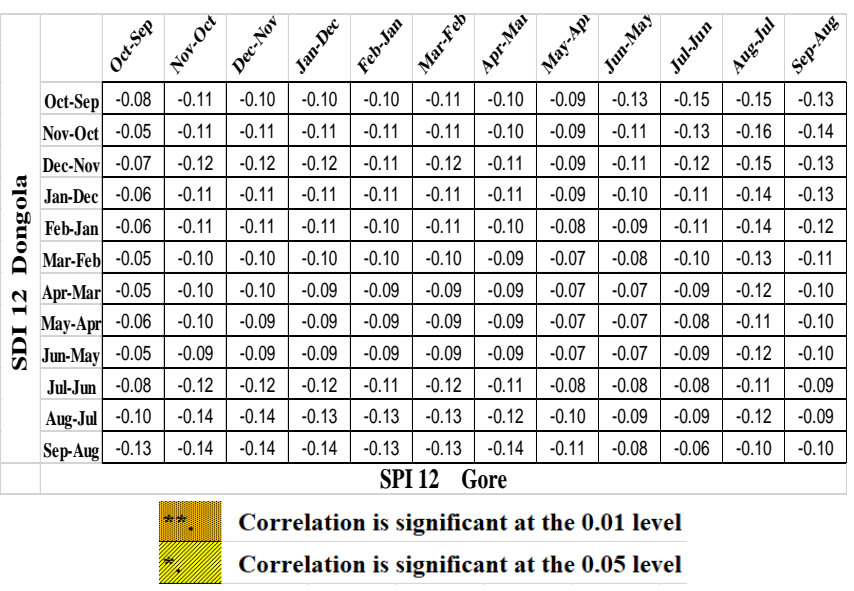

\section{CONCLUSION}

There are three seasons in Ethiopia for precipitation distributions. Kiremt (JJAS) is the main rainy season from June to September, Bega (ONDJ) is the dry season from October to January, and Belg (FMAM) is the small rainy season from February to May. After analysis of monthly values of SPI at five meteorological stations in the Upper Blue Nile Basin, it was noticed that the SDI at Dongola station is more affected by the drought at Bahar Dar, Debremarkos and Gore. The values of SPI at Gore station indicates droughts in periods that are common with SDI drought at Dongola station. Pearson correlation coefficients between each SPI and SDI intervals in different time ranges for 1, 3, 6, 9 and 12 months show some significant correlations at $5 \%$ and $1 \%$ level of significance. The frequency of statistical significance correlation is moderate at the monthly scale, where it reaches its maximum at the 3 months' scale, followed by the 6 months' scale, and less frequently at the 9 months' scale. While, no significance was found at the 12 months' scale. SPI at Gore station represents the highest frequency of significance with SDI at Dongola station in different time scales, confirming the relationship between SPI for Gore Station and SDI for Dongola station. The rapid population growth in Africa expanding the water demand for water adds a high significance to drought assessment, Hence, it's necessary to improve techniques for monitoring drought hazards in precipitation zones in East Africa and assess more meteorological stations to accurately predict climate change variations with a level of confidence.

\section{REFERENCES}

1. M. T. Alrajoula, I. S. Al Zayed, N. A. Elagib, M. R. Hamdi, Hydrological, socio-economic and reservoir alterations of Er Roseires Dam in Sudan. Science of the Total Environment, 2016, 566, pp.938 948.

2. H. Akbari, G. R. Rakhshandehroo, A. H. Sharifloo, E. Ostadzadeh, Drought Analysis Based on Standardized Precipitation Index (SPI) and Streamflow Drought Index (SDI) in Chenar Rahdar River Basin, Southern Iran. Watershed Management Symposium, August 5 - 7, 2015, American Society of Civil Engineers.

3. A. Dawit, Future climate of Ethiopia from PRECIS Regional Climate Model Experimental Design. Ethiopia, 2010, http://www. metoffice. gov. uk/media/pdf/o/9/PRECIS_Experimental_Design_Dawit. pdf (accessed 10 August 2013).

4. X. Hong, S. Guo; Y. Zhou, L. Xiong , Uncertainties in assessing hydrological drought using streamflow drought index for the upper Yangtze River basin. Stoch. Environ. Res. Risk Assess, 2014, 29: pp. 1235 - 1247.

5. H. Jamshidi, D. Khalili; M. R. Zadeh, Z. Hosseinipour, Assessment and Comparison of SPI and RDI Meteorological Drought Indices in Selected Synoptic Stations of Iran. World Environmental and Water Resources Congress 2012.

6. A. Jarvis, H. I. Reuter, A. Nelson, E. Guevera, Hole-filled SRTM for the globe Version 4. CGIAR - consortium for spatial information, 2008. http://srtm.csi.cgiar.org/.

7. H. K. Ntale, T. Y. GAN, Drought indices and their application to East Africa. International Journal of Climatology: A Journal of the Royal Meteorological Society, 2003, 23, pp. 1335 - 1357.

8. M. Özcan, V. Gümüş, O. Şimşek, M. Şeker, Drought Analysis of Bitlis River Baykan Station with Streamflow Drought Index (SDI) Method, journal of Academic Perspective Procedia, 2019 ISSN: 2667-5862, 2, PP. $1100-1106$.

9. A.A. Pathak, B. M, Dodamani, Comparison of Meteorological Drought Indices for Different Climatic Regions of an Indian River Basin. Asia-Pacific J Atmos Sci, 2019.

10. M. E. M. Omar, A. Moussa, Water Management in Egypt for Facing the Future Challenges, Journal of Advanced Research, 2016, 7, pp. 403 -412 .

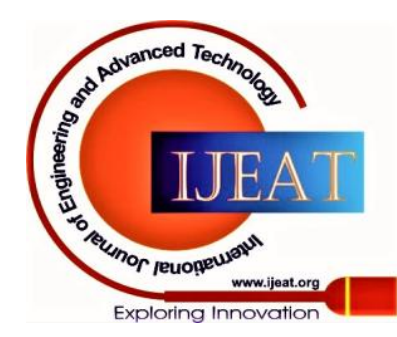


11. A. A. Pathak, B. M. Dodamani, Comparison of two hydrological drought indices. Perspectives in Science, 2016, 86, pp. 626 - 628.

12. T. G. Romilly, M. Gebremichael, Evaluation of satellite rainfall estimates over Ethiopian river basins. Hydrology and Earth System Sciences, 2011, 15, pp. 1505 - 1514.

13. H. Shang, J. Yan, M. Gebremichael, S. M. Ayalew, Trend analysis of extreme precipitation in the Northwestern Highlands of Ethiopia with a case study of Debre Markos. Hydrology and Earth System Sciences, 2011, 15, pp. 1937 - 1944.

14. G. Tsakiris, I. Nalbantis, H. Vangelis, B. Verbeiren, M. Huysmans, B. Tychon, I. Jacquemin, F. Canters, S. Vanderhaegen, G. Engelen, A system-based paradigm of drought analysis for operational management. Water resources management, 2013, 27, pp. 5281 5297.

15. S. M. Vicente, S. Begueria, J. I. LÓPEZ-MORENO, A multiscalar drought index sensitive to global warming: the standardized precipitation evapotranspiration index. Journal of climate, 2010, 23, pp. 1696 - 1718.

\section{AUTHORS PROFILE}

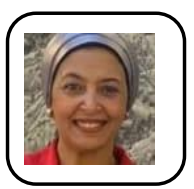

Eng. Eman Mabrouk is a civil engineer, Faculty of civil engineering, Alexandria University. She worked at the Egyptian General Authority for Drainage Projects (EPAD) at the Ministry of Water Resources and Irrigation since 1997 She is currently an Inspector of Irrigation in Technical office of EPAD Chairman. She had a Diploma in Natural resources in 2017, a Diploma in Meteorological Studies in 2018, and a Master degree in Meteorological studies in 2019 from Faculty of African Postgraduate Studies, Cairo University. She is very interested in the field of water management and irrigation, and meteorological studies.

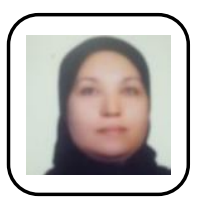

Prof. Dr. Fawzia Morsy is a Prof. of Physical Meteorology, Cairo University, Faculty of African Postgraduate Studies, Department of Natural Resources. She was the head of Department of Natural Resources at Faculty of African Postgraduate Studies, Cairo University. She is currently a staff member in the Department of Natural Resources. She has shared in establishing, preparing and building the laboratories of Natural Resources Department. She has participated in many different of conferences and symposiums and writing of African studies (Chapter of Africa climate, sixth folder, Book of Natural resources in Africa, Faculty of African Postgraduate Studies, Cairo University, 1997). She is a member in laboratories committee and scientific devices, environmental, and social service, social committee, culture committee for external relationship, Centre of African environmental researches. She has more than thirty scientific publications in climatic changes, water resources and applied research in impacts of climate change on Africa, sustainable development of natural resources in the Nile basin countries and the potentialities of integration and development of water and energy in the Nile basin. She has more than 42 scientific supervisions (M.Sc and Ph.D) in Meteorological and their various applications in Africa and the environment and water resources management. She specializes in agro meteorological research evaluation and impact assessment, monitoring of the climatic changes on Africa.

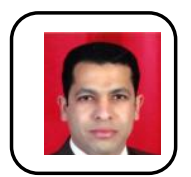

Dr. Mostafa Mohamed is a lecturer of Meteorology and statistical analyses at the Natural Resources Department, Faculty of African Postgraduate Studies, Cairo University, Egypt. His scientific degrees are Bachelor of Science from Astronomy and Meteorology department, Faculty of Sciences, El Azher University, Master of Science (Meteorology) from Faculty of African Postgraduate Studies, Cairo University, Egypt, and PhD of Science (Meteorology) from Faculty of African Postgraduate Studies, Cairo University, Egypt. His academic appointments are Teaching assistant, assistant lecturer and lecturer in department of Natural Resources, Faculty of African Postgraduate Studies in Cairo University, Egypt. He has eight scientific publications about climatic changes, water resources and applied research in the field of meteorology, possible impacts of climate change on Africa, sustainable development of natural resources in the Nile basin countries and the potentialities of integration and development of water and energy in the Nile basin.

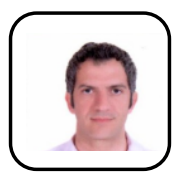

Dr. Mohie Omar is an Associate Professor and Senior Technical Officer at the President's Technical Office of the National Water Research Center in Egypt, and a Postgraduate Instructor at Faculty of African Graduate Studies at Cairo University in Egypt. Previously, his career

Published By:

Blue Eyes Intelligence Engineering \& Sciences Publication (C) Copyright: All rights reserved. in Egypt included a series of occupations at the German Society for International Cooperation (GIZ), and the Planning Sector of Ministry of Water Resources \& Irrigation. His international experience has been obtained through his occupations and consultancy services at UNESCO-IHE in the Netherlands, and the Technische Universitaet Berlin and the Leibniz Centre for Agricultural Landscape Research in Germany. He has seventeen scientific publications. He has been conducting various research activities for water resources planning at governorate and national scale, enhancement of irrigation practices, environmental hydrology and developing nonconventional water resources. 